\title{
"Voces" de Carlos Ruiz Espinoza
}

Por Erwin Silva ${ }^{1}$

Carlos Ruiz Espinoza (Managua, 1956) vivió en Costa Rica desde 1957 hasta 1973, donde estudió la educación primaria y secundaria. En 1974 llegó a Nicaragua y estudió Ciencias Económicas en la UNAN Managua. En 1978 regresó a Costa Rica donde vive actualmente y ejerce como Abogado y Notario público y desde hace 15 años es profesor de la Universidad Fidelitas.

Gran parte de su obra ha permanecido inédita y esta selección de sus textos poéticos la hemos tomado de su libro "VOCES" (2014).Este poemario lleno de vida y de memorias quiere llevarnos a la sencillez de una sabiduría pero con un trasfondo de lo eterno, de lo permanente en un mundo donde lo pasajero, el amor, la guerra, las pérdidas irreparables y aun los sueños, nos conducen también a una doliente deriva de la nostalgia.

La única publicación de Carlos Ruiz que se registra en Nicaragua es su poema "Cuando los días" en los años noventa y apareció en la revista experimental jinotepina "La Pluma del Cuervo" entonces dirigida por el músico y poeta Martin Aguilar.

La revista Cultura de Paz se complace con la presentación de estos poemas de Carlos Ruiz, seguros de que calan por su sensibilidad educada en los grandes poetas de América y traslucen una cultura literaria que puede leerse debajo de sus versos.

\section{Selección de Poemas del libro VOCES de Carlos Ruiz Espinoza}

\section{Soledad}

iOh, Poesíai vagabunda que te pierdes y que de repente apareces como quien se ha perdido en un bosque salvaje. En medio del alba, del día o de la noche, sin tocar a la puerta te sientas a mi mesa, comes de mi pan, bebes de mi vino, y a cada instante me recuerdas que debo cumplir con mi destino. Y lo extraño es que no sé porqué, prefiero tu soledad a las riquezas de este mundo.

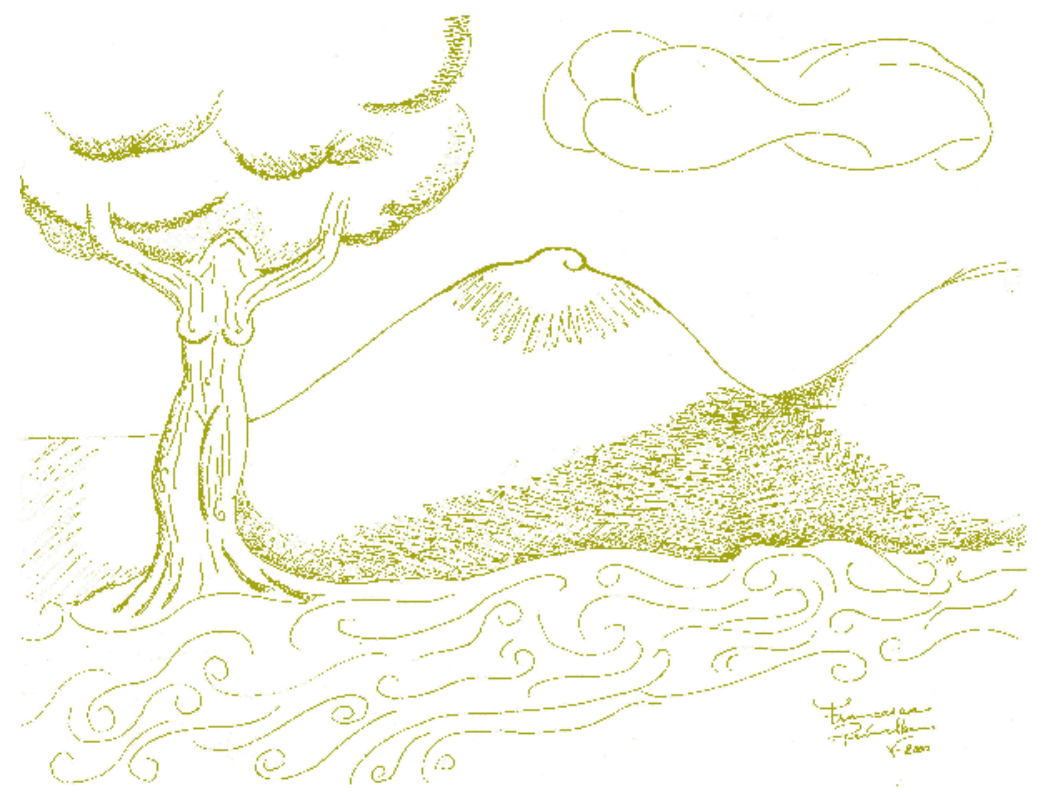

1 Poeta y escritor nicaragüense, Coordinador del Área de Educación para la Paz y Derechos Humanos del Instituto "Martin Luther King" de la UPOLI, Managua, Nicaragua, 2014. 


\section{Literatura}

\section{Verano inmenso}

En días como estos

en que la tarde se pierde

en los tonos grises del pasado,

recuerdo cuando tu rostro se multiplicaba

como una magia en mi ventana;

cuando en medio del letargo

de un verano inmenso

supe que te amaba;

cuando todas las canciones

que se escuchaban en la radio

parecía que habían sido

inspiradas por tu nombre.

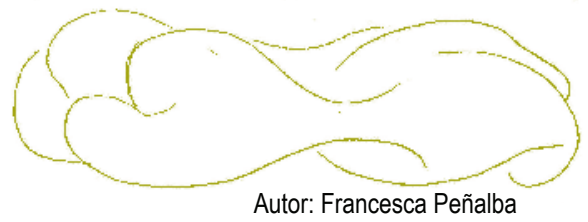

\section{Lejanía}

¿Cómo pudimos saber que se agitaría la bierba

$Y$ se alzaría la polvareda en el viento?

\section{Li Tai Po}

Como puñal de cuatro filos quedó clavado en mi costado

el adiós de tu mirada.

Sin adivinarlo,

sin decirnos adiós,

mientras la hierba se agitaba en el viento

nos despedimos para siempre.

Luego vendría la guerra,

la soledad, el abandono,

la muerte lenta

en medio de la separación definitiva

de todas las cosas

que poco a poco fui perdiendo.

Desde entonces

busco tu sonrisa

en medio de caminos solitarios

perdidos en el tiempo.

\section{Flor de Crisantemo}

¿A qué amurallar la ciudad si al anochecer

desconocidos

penetrarán sus fuertes muros

y derribarán todas las estatuas;

si esta noche

al amanecer

solo quedará el humo

ascendiendo entre las ruinas?

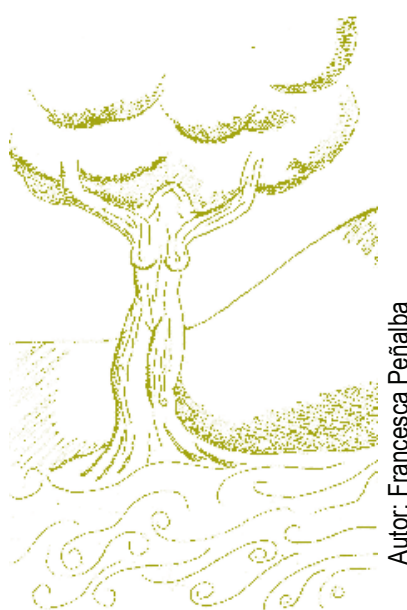

PRIMAVERA ZEN

Una luna inmensa y amarilla

ilumina las nieves

que se derriten al pie de la montaña.

Las grullas coloradas

han vuelto al antiguo monasterio

de los monjes tibetanos,

y en medio del silencio de la noche

una brisa delicada

agita los blancos crisantemos.

La sucesión infinita del tiempo

siempre repite este paisaje

de primaveras y lunas siempre renacientes

donde todo pasa y todo permanece.

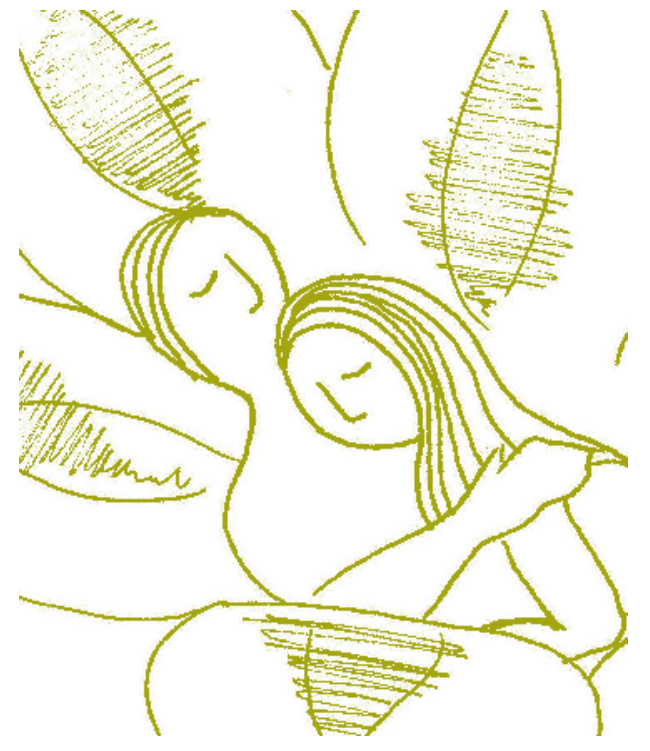

